\title{
Growing pains: Edward Partington and the early wood pulp industry in New Brunswick, 1890-1910
}

\author{
by Bill Parenteau ${ }^{1}$
}

\begin{abstract}
The story of the dramatic rise of pulp and paper as the most important manufacturing industry in Canada by the end of the 1920s is well known. Less well known are the difficulties of the industry in its early years of development (1890-1910). The pool of technical and mechanical knowledge in Canada to run a pulp and paper mill was shallow. In addition, markets tended to be unstable and access to sufficient quantities of capital and wood was precarious in some places. There were notable successes but also enough errors to doom a large number of enterprises. New Brunswick mills experienced all the pitfalls of pulp production during this era, none more so than the Cushing Sulphite Fibre Company, despite the fact that the main financier and the mill manager were prominent figures in the early history of the industry.
\end{abstract}

Keywords: wood pulp, forestry industries, New Brunswick, Edward Partington

\section{ABSTRACT}

The story of the dramatic rise of pulp and paper as the most important manufacturing industry in Canada by the end of the 1920s is well known. Less well known are the difficulties of the industry in its early years of development (1890-1910). The pool of technical and mechanical knowledge in Canada to run a pulp and paper mill was shallow. In addition, markets tended to be unstable and access to sufficient quantities of capital and wood was precarious in some places. There were notable successes but also enough errors to doom a large number of enterprises. New Brunswick mills experienced all the pitfalls of pulp production during this era, none more so than the Cushing Sulphite Fibre Company, despite the fact that the main financier and the mill manager were prominent figures in the early history of the industry.

Keywords: wood pulp, forestry industries, New Brunswick, Edward Partington

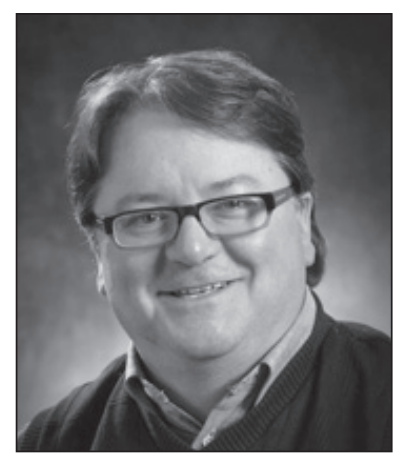

Bill Parenteau
The story of the dramatic rise of pulp and paper as the most important manufacturing industry in Canada by the end of the 1920s is well known. In brief, the final removal of the United States tariff on newsprint and wood pulp in 1913, combined with the deterioration of pulpwood supply in the northeastern United States and the vast forest resources and hydro-electric potential in the eastern provinces to set off what was, arguably, the most significant industrial development in $20^{\text {th }}$ century Canada. From a relatively insignificant position in 1910, Canada became the world's leading manufacturer of newsprint paper by the late 1920s.

Less well known are the difficulties of the industry in its early years of development. During the period from around 1890, when sustained interest and investment in pulp and paper mills began, until around 1910, the industry often promised more than it delivered. The pool of technical and mechanical knowledge in Canada to run a pulp and paper mill effectively was shallow and held by individual engineers/mill managers (Hull 1983). In addition, markets tended to be unstable and access to sufficient quantities of capital and wood was precarious in some places. It was an era of trial and error; there were notable successes but also enough errors to doom a large number of enterprises. New Brunswick mills experienced all the pitfalls of pulp production during this era, none more so than the Cushing Sulphite Fibre Company, despite the fact that the main financier and the mill manager were prominent figures in the early history of the industry.

Paper was manufactured from rags in New Brunswick as early as 1826; however, it was not until around the time of Canadian Confederation that wood fibre was used for pulp and paper making in the province. The earliest wood pulp mill was, perhaps, the Philps mill opened in 1863 two miles east of Saint John on Little River. Little is known of the mill except that it burned to the ground in 1867 and was insured for just $\$ 5000$. The small Philps mill was followed by a succession of other similarly marginal operations during the following 20 years. They included the short-lived New Brunswick Paper Mills of St. John (1867-1871) and the New Brunswick Paper Manufacturing Company mill built near Sussex around the same time. The Sussex mill survived until 1885 when it was destroyed by fire, but never produced pulp valued at more than $\$ 40000$ in any single year (Carruthers 1947). 
The 1890s saw an expansion in the pulp industry, as by this time chemical processes for separating fibre from wood were progressing and optimism for the future of the industry was high throughout Canada. During the 1890s groups of local entrepreneurs on nearly every major watershed of the province investigated the possibilities of erecting a pulp mill (e.g., rumours in The Canada Lumberman in August 1897, July 1899, and June 1904 and Johnson 1983). Many of these promotional schemes never came to fruition; however, by the turn of the century new mills had been established near the harbours on the St. John and Miramichi Rivers. The St. John Sulphite Pulp Company went into production in 1899 at a rated capacity of 25 tons per day. It was organized by B. Mooney and Sons, a St. John lumber firm, and financed with Scottish capital. Similarly, the second Saint John mill was the brain-child of an established Saint John lumberman, George Cushing, and funded by British capital. The Cushing Sulphite Fibre Company, which opened in 1900 with a rated capacity of 35 tons per day, had as its principal stockholder British pulp and paper magnate Edward Partington. He owned three pulp and paper mills in England that employed more than 1000 hands. His status as an industrialist of note was acknowledged in 1914 when he was knighted as $1^{\text {st }}$ Baron of Doverdale. The St. George Pulp and Paper Company, the last of what could be termed a first generation of mills, went into production at St. George, Charlotte County in 1903. It was owned by an American paper company from Norwalk, Connecticut and had a rated capacity of 30 tons of groundwood pulp per day (Carruthers 1947, Glendenning 1974, Côté 1978). It was also the only successful enterprise, as the others were beset by a variety of problems that included poor management, ownership divisions, lack of technical expertise, insufficient capital, unstable markets and a weak position with regard to natural resources.

The bankruptcy records of the Cushing Sulphite Fibre Company provide a good account of the trouble-plagued New Brunswick pulp industry at the turn of the century. In June 1898 the Cushing Sulphite Fibre Company was incorporated with George Cushing and four other Saint John merchants comprising the board of directors. The pulp facility was to be built adjacent to the Andre Cushing Company sawmills near the Reversing Falls in Saint John; this arrangement reduced the cost of purchasing real estate and it was intended that the pulp mill would consume the slabs and other waste wood from the sawmill. Construction of the mill did not begin until the summer of 1900 and the first wood pulp was manufactured in October. Already by this time significant changes in the firm's management were underway. As the Saint John merchants did not possess the financial resources to build the mill themselves, they advertised a sale of stock in the United States and England. They were successful in attracting the interest of Edward Partington, who, in addition to owning pulp and paper companies, held a directorship in the Manchester and Liverpool Bank. Partington bought 5600 shares of the 10000 share stock issue between July and November 1900; British associates of Partington bought additional smaller quantities of stock. In preparation for the large purchases, Partington was unanimously elected President of the company in March 1900 (Canada Lumberman 1898, PANB 1900, Carruthers 1947.)
Meanwhile, the mill itself was off to an inauspicious beginning. The Cushing sawmill could not produce sufficient slab wood to sustain production in the pulp mill, which, consequently, operated at far below its capacity. In March 1901 there was more bad news when the company's auditor informed the shareholders and directors that "the manufacture of pulp up to the present has been conducted at a considerable loss". By mid-May the company had burned through all its operating capital and because the enterprise had failed to show any signs of succeeding, the Saint John directors were unable to secure a bank loan to keep the fledgling mill open. They approached Partington with a scheme to issue bonds. Partington agreed to an issue of $\$ 300000$ worth of bonds bearing $10 \%$ per annum, if the board of directors submitted to certain conditions. The conditions included Partington retaining "absolute control of management", the appointment of Charles Springer of Boston, a Partington representative, to the board and "all wood used for the pulp mill from starting to date shall only be charged on prices it netted Andre Cushing before the pulp mill started" (PANB 1901a).

Reluctantly, the Board of Directors agreed to Partington's conditions, which signaled the passing of local control over the affairs of the company. In July Partington sent James Beveridge, an experienced pulp and paper engineer, to Saint John to manage the mill. Indeed, Beveridge was an industry figure of some renown having authored one of the early manuals on wood pulp and paper making (Beveridge 1901). This meant that George Cushing was forced to relinquish his position as Managing Director; apparently Cushing did not favour the change, as he resigned from the Board of Directors on 24 July 1901.

The problems between Cushing and Partington were just beginning, as the two enterprises continued to be integrated and the relationship between the two owners became petty and vindictive. The financial condition of the company was such that James Beveridge, upon his arrival in mid-July, was forced to buy 10000 pounds sterling worth of bonds to keep the mill running. Beveridge continued to advance cash to the company in exchange for bonds for the next two months. This helped keep the mill producing, but by the end of September the company's creditors were beginning to get anxious. Having failed to get a loan from the Bank of British North America to pay off the Bank of Nova Scotia, the board of directors began pleading with creditors to accept bonds as payment on accounts. The almost pathetic financial position of the company was evident at a 1 October 1901 meeting, when the board members engaged in a heated discussion over whether to pay all liabilities under $\$ 25$, or treat all creditors alike. At the same meeting it was decided, after lengthy debate, to keep the mill open, despite the fact that it was still "being worked at a considerable loss" (PANB 1901b).

The Cushing Sulphite Fibre Company mill stayed open for another three years but never recovered from the problems encountered during its first year of operation. On 27 December 1901 the board of directors decided that "in view of the financial position of the company it is not possible to pay the interest on the bonds of the company which falls due on January first next." Subsequently, the company failed regularly to meet its obligations to bond holders. After January 1902 nearly all purchases for materials and services had to be guaranteed personally by 
either Partington or Beveridge. There were also technical problems with the mill. Frequent breakdowns of machinery and inconsistencies with the pulp screening process hampered production and eventually led to the firing of persons held responsible. In December 1902 the company was forced to make improvements to the mill when the Mutual Fire Insurance Company informed them that unless the main water pipe in the plant was increased from six to ten inches in diameter its policy would be cancelled.

The growing animosity between Edward Partington and George Cushing only added to the problems. Partington believed that Cushing had over-charged the pulp operation for the slab wood used in the mill during its first year of operation. After failing to come to an agreement the issue was settled by a court in Cushing's favour in February 1904. A few months later Cushing notified the pulp company that they would no longer be allowed to use the holding pond below the mill to store pulpwood. This precipitated another legal suit between the two men over the rights to the riverfront properties below the mill. Shortly thereafter Partington threatened to file suit against Cushing if he did not contain the sparks from the sawmill chimney, which the British financier claimed were creating a fire hazard. In apparent retaliation Cushing ordered the managers of the pulp mill to vacate offices that he had been renting to them (PANB 1901c, 1902, 1904a).

Creditors of the beleaguered pulp mill finally lost their patience in 1905. On 28 December 1904 the board of directors was informed that the Eastern Trust Company would begin foreclosure proceedings unless they received $\$ 7000$ in accrued interest on bonds within 10 days. Ironically, as the weight of accumulated debt was about to crush the company, the pulp operation showed a profit for the first time in the year ending 28 February 1905; the board of directors celebrated by awarding themselves bonuses totaling $\$ 1000$. Less than two months later the board was served with a notice to "answer to an application from Mr. George S. Cushing that a Receiver be appointed for winding up the company." The board was instructed by Partington to resist the application. In early June Cushing offered to drop the application if Partington paid all court fees and agreed to withdraw his claim to the millpond. It was a clever manoeuvre in the war of nerves between the two rivals, but their nasty little contest was quickly coming to an end. By mid-June the Eastern Trust Company had forced a foreclosure on the company and taken possession of the mill properties. The mill was kept operating under a licence agreement, which was eventually cancelled in September 1905. The mill was not opened again until 1907, when favourable tax concessions with the City of Saint John were negotiated and the company was reorganized as the Edward Partington Paper Company (PANB 1904b, 1905; Glendenning 1974).

The early history of the Cushing mill reflected the growing pains that the pulp industry was having in New Brunswick and elsewhere. Building a pulp mill seemed like a good idea, but there were barriers to success even beyond those that inhibited the Cushing Company. Given the fluctuation in prices for pulp it was difficult for the New Brunswick mills, all of which produced fewer than 50 tons per day, to take advantage of favourable market conditions even when they did occur. The American tariff on pulp and paper products before 1913 limited to some degree the export market for Canadian mills almost exclusively to Great Britain, where they had to compete with better-located European mills. Finally, until the province passed the "manufacturing condition" in 1911, banning the export of pulpwood from Crown lands, local pulp mills had to compete with larger American companies, especially International Paper, which were accumulating large tracts of forest that came on the market as a result of a wave of lumber company bankruptcies around the turn of the century.

As was the case with the other three pulp mills in New Brunswick at the time, the Partington Company got swept up in the rapid expansion and reorganization of the pulp and paper industry in Canada in the 1910s. Partington placed his company on more solid footing on the eve of the First World War when he bought the equipment of the defunct Saint John Pulp and Paper Company, and the timberlands that went on the market as a result of the collapse of Alexander "Boss" Gibson's commercial empire on the Nashwaak River. Gibson owned the largest producing lumber operation in the Maritimes by the early 1880s; however, some contentious and unsuccessful railroad ventures and then the bankruptcy of his cotton mill in the company town of Marysville left him with only a $\$ 5000$ per year pension and the use of his stately home. Additional equipment, tax relief and, especially, the 578 square miles (149 $700 \mathrm{ha}$ ) of timber limits obtained from Gibson (353 freehold and 225 Crown land), allowed the company to upgrade production to 50 tons per day.

In 1916 the Edward Partington Company was purchased by Oxford Paper of Rumford, Maine and became the Nashwaak Pulp and Paper Company. Thereafter, the pulp produced at the mill was sent to two Oxford Company paper mills in Maine. Oxford continued to produce pulp at the mill until 1930 when it announced a permanent shutdown (Pulp and Paper Magazine of Canada 1912, 1916, 1930; Carruthers 1947; Glendenning 1974, 1983). By this time the mill was something of a relic of a by-gone age, as the 1920s had seen a massive expansion of the industry in Canada. More and more it became dominated by technologically advanced, multi-million dollar mills, which held thousands of square miles of timber rights, had access to hydroelectric power and produced as much as 600 tons of pulp and paper per day. New Brunswick participated fully in this process; by 1930 three pulp and paper companies-International Paper Company, Fraser Company Ltd. and the Bathurst Power and Paper Company-controlled 70\% of the industrial forest in the province and virtually all of the developed hydro-electric power.

\section{References}

James Beveridge. 1901. The Papermaker's Pocketbook: Specially Compiled for Paper Mill Operatives, Engineers, Chemists and Office Officials. McCorquodale, London.

Carruthers, G. 1947. Paper in the making. Garden City Press Cooperative, Toronto, $\mathrm{ON}$.

Côté, S. 1978. Origins of the First Pulp and Paper Mills in New Brunswick. Paper presented to the $13^{\text {th }}$ Annual Conference of the Atlantic Association of Sociologists and Anthropologists, March, 1978.

Glendenning, B. 1974. The New Brunswick Pulp and Paper Industry, 1900-1930. Unpublished paper, Concordia University, Montreal, QC. Glendenning, B. 1983. Crown Land Regulations and the Introduction of the Pulp and Paper Industry to New Brunswick. Unpublished paper. Hull, J.P. 1983. From FPL to Paprican: Science and the Pulp and Paper Industry. HSTC Bulletin 7(1): 1-13. 
Johnson, C.A. 1983. The Search for Industry in Newcastle, New Brunswick, 1899-1914. Acadiensis XIII 1: 93-111.

Parenteau, B. 1992. The Woods Transformed: The Emergence of the Pulp and Paper Industry in New Brunswick, 1918-1931. Acadiensis XXII(1): 5-43.

[PANB] Provincial Archives of New Brunswick. 1900. Minutes of the Meeting of the Board of Directors, Cushing Sulphite Fibre Company, Book I, entry for 3 March 1900; and Stock Ledger of Cushing Sulphite Fibre Company, pp. 1-5, in RS 53, Supreme Court Bankruptcy Records, Section 1, \#2.

. 1901a. Minutes of the Meeting of the Board of Directors, Cushing Sulphite Fibre Company, Book I, entries for 6 March 1901, 28 May 1901, RS 53, Supreme Court Bankruptcy Records, Section 1, \#2.

. 1901b. Minutes of the Meeting of the Board of Directors, Cushing Sulphite Fibre Company, Book I, entries for 16 July , 24 July 1901, 14 August 1901, 13 September 1901, 1 October 1901, RS 53, Supreme Court Bankruptcy Records, Section 1, \#2.

. 1901c. Minutes of the Meeting of the Board of Directors, Cushing Sulphite Fibre Company, Book I, entry for 27 December 1901, RS 53, Supreme Court Bankruptcy Records, Section 1, \#2.
1902. Minutes of the Meeting of the Board of Directors, Cushing Sulphite Fibre Company, Book I, entry for 2 December 1902, RS 53, Supreme Court Bankruptcy Records, Section 1, \#2.

. 1904a. Minutes of the Meeting of the Board of Directors, Cushing Sulphite Fibre Company, Book II, entries for 12 February 1904, 1 July 1904, 16 August 1904, RS 53, Supreme Court Bankruptcy Records, Section 1, \#2.

. 1904b. Minutes of the Meeting of the Board of Directors, Cushing Sulphite Fibre Company, Book II, entry for 28 December 1904, RS 53 , Supreme Court Bankruptcy Records, Section 1, \#2.

. 1905. Minutes of the Meeting of the Board of Directors, Cushing Sulphite Fibre Company, Book II, entries for 13 February 1905, 26 April 1905, 5 May 1905, 5 June 1905, 12 June 1905, 22 June 1905, RS 53, Supreme Court Bankruptcy Records, Section 1, \#2.

Pulp and Paper Magazine of Canada. 30 April 1912, 15 December 1916, 25 September 1930.

The Canada Lumberman. August 1897, June 1898, July 1899, June 1904. 